\title{
Plant Production Research in Finland in the 1970s and 1980s
}

\author{
JAAKKO MUKULA \\ Agricultural Research Centre, Department of Soils and Crops \\ SF-31600 Jokioinen
}

\section{Introduction}

In Finland, the area of arable land used for plant production was some 2.5 million hectares in 1970. Owing to surplus production, the area was reduced to 2.0 million hectares by the end of the $1980 \mathrm{~s}$. During this period the number of farms ( 1 ha or over) declined from 290000 to 190000 .

The fields are located between the latitudes of 60 and $67^{\circ} \mathrm{N}$ (Fig. 1). The growing season $\left(+5^{\circ} \ldots+5^{\circ} \mathrm{C}\right)$ is about $170-180$ days long in the south and 130-135 days in the north. The effective temperature sums (above $+5^{\circ} \mathrm{C}$ ) are $1200-1300$ Gdd and 750-800 Gdd, respectively. The mean temperature of the warmest month, July, is $16-17^{\circ} \mathrm{C}$, and total precipitation during the growing season 250 $300 \mathrm{~mm}$. The most common soil types are various mixtures of glacial till, sand, silt, clay and peat. The major field crops are cereal grains, grasses for hay and silage, oil seed rapes, potato and sugar beet. Production of horticultural plants is also significant.

Plant production research is carried out in Finland by several institutes and regional experimental stations, most of them belonging to the two governmental organizations, the Agricultural Research Centre of Finland
(ARC) and the Faculty of Agriculture and Forestry of Helsinki University (HU). In the private sector, several commercial companies are also contributing, either alone or jointly with the governmental organizations.

During the 1970s and 1980s some marked changes took place in the research organizations and their location in Finland. The major institutes of the ARC were transferred from the Helsinki area to Jokioinen, located $130 \mathrm{~km}$ northwest of Helsinki. Some new experimental stations were also established (Fig. 2).

The objectives of plant production research in Finland have been to secure domestic supply of food and fodder, taking into consideration both the nutritional and technical quality of products. The regional extent of production and its geographical location in relation to climatic and ecological conditions as well as the agricultural and marketing policy are also taken into account.

During the period of this study the general trend of plant production research was shifted towards more interdisciplinary studies and specific research projects. More attention was payed to environmental factors like less pol- 


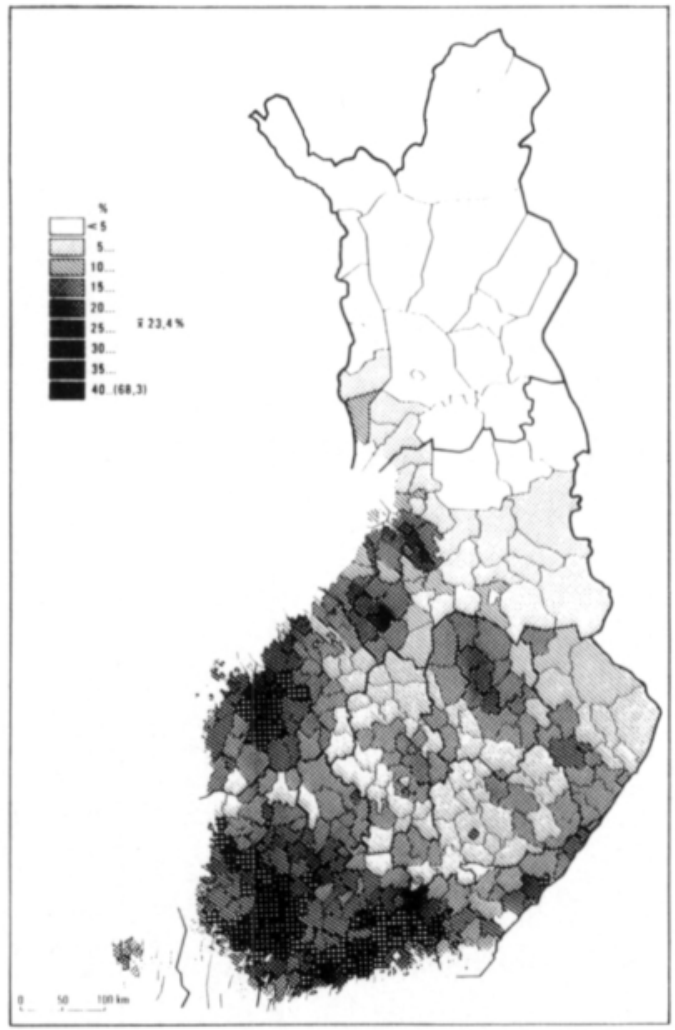

Fig. 1. The geographical distribution of arable land in Finland. (Source: Atlas of Finland 1982:11g.)

luting cropping systems and product quality.

Most of the plant production research conducted in Finland is financed from the annual state budget. During the period of this study a larger sum was allocated for the building of new laboratories and for supplying the institutes with new scientific equipment. Finance for the implementation of research work remained about the same as previously. Two annual budgetary appropriations were granted, however: one to support joint, interdisciplinary research projects (1975) and another to support research into environmentally safe plant production methods (1983). In addition, increased contributions from commercial companies made it possible to enlarge the scope of experimental work in certain areas of plant production. The same was true for private or semi-governmental foundations, the Academy of Finland and SITRA in particu-

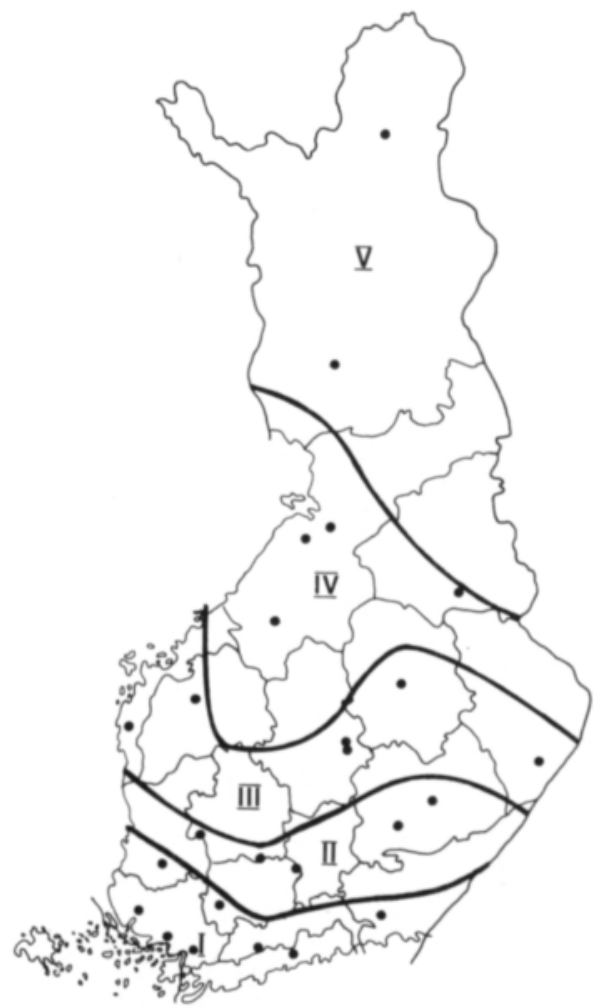

Fig. 2. Agricultural institutes, experiment stations (•) and cultivation zones $(\mathrm{I}-\mathrm{V})$ for field crops production.

lar. The amount of parlamentary money spent annually on plant production research was about FIM 50-60 million and that of the private sector FIM 20-25 million corresponding to about $400-450$ person in manpower.

\section{Soils and soil management}

Regional mapping of soils suitable for plant production used to be carried out in Finland by the Department of Soil Science of the ARC. Collecting soil samples was continued by the department until 1975 and printing of maps until 1988. About 200 sheets at a scale of $1: 20000$ were the result of these studies. In 1979 the government's Board of Topography and the Institute of Geology jointly took the responsibility for continuing soil mapping.

During the period of this study (1970 - 1989) 


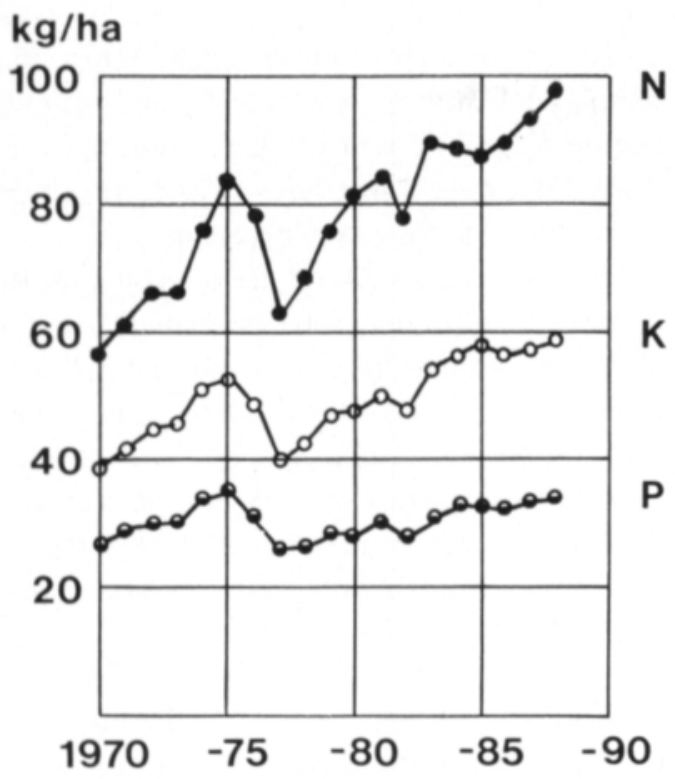

Fig. 3. The rate of main nutrients yearly used in commercial fertilizer mixtures, kg/ha. (Source: Kemira Ab.)

the Department of Soil Science participated in the global assessment of soil micronutrients sponsored by FAO SillanpäÄ (1982). Regional assessment of soil micronutrient is still on the department's programme at the country level (SillanPäĂ 1988).

A private company called Soil Fertility Services carried out soil fertility studies with a view to providing farmers with the information necessary for fertilizing their fields properly. Country-wide summaries of these studies were published by KURKI (1982) and KÄHÄrı et al. (1987). Special studies of several mineral elements were carried out in cooperation with other institutes.

The use of chemical fertilizers increased until the mid 1970s (Fig. 3). A method to place the fertilizer under soil surface between the seed rows was developed in the 1960s and adopted in farming practice at the beginning of this study period. Special equipment made it possible to sow and fertilize simultaneously (cf. OKSANEn, in this volume). The placement technique led to a considerable improvement in the degree of utilization of fertilizers by plants. Nevertheless, about $40 \%$ of nutrients were not taken up by plants and entered water courses, the atmosphere or ground soil as useless compounds (ELONEN 1984). This had detrimental impact on the environment. Intensive research work was done to establish nutrient losses and how to reduce them. Some imbalance in soil nutrients was also found when using heavy nitrogen fertilization. Nitrogen apparently stimulated plant's utilization of other nutrients, potassium in particular.

In the 1980s new experiments were conducted to determine the optimum amount of commercial fertilizers to be used for field crops. Owing to the low level of selenium in Finnish soils it was decided to add this element to commercial fertilizer mixtures (YLÄRANTA 1983). Several field experiments were also carried out with farm yeard manure, ash, organic sludge and other substances from the waste waters of populated areas and factories. Certain heavy metals, especially cadmium and lead, proved problematic in the use of sludge.

There is often a special need for soil irrigation in some parts of southern Finland, where early summer drought frequently limits the growth of plants. Sprinkler irrigation was introduced in the early 1970s (ELONEN 1983). By the end of this study period about 10000 sprinkler units were in use with the maximum capacity of 100000 ha.

Soil compaction due to the use of heavy machines and carriers on fields is a difficult problem. Efforts were made to ease it by fitting double tyres to tractors and carriers. Experiments were also made using deep cultors and rotary harrows. To improve the seed bed preparation special warping equipment was added to conventional harrows (cf. OKSANEN, in this volume).

\section{Plant breeding}

Finland's location at the northern limit of plant production makes it difficult to cultivate foreign varieties. The main climatic factors 
limiting plant production are the short growing season with its low effective temperature sum and the hard winter. Hence, the domestic plant breeding is important.

During the 1970s and 1980s the breeding of field crops continued intensively at the Plant Breeding Institute of the Hankkija Cooperative Company under Professor Erkki Kivi and at the Department of Plant Breeding of the ARC under Professor Rolf Manner. The Hahkiala Training and Experimental Farm of the Kesko-Group contributed as a part of a contract with Swedish Svalöf Ab. In 1985, a similar contract was made by Suomen Vilja (the Finnish Cereal) and the Swedish Plant Breeding Institute of W. Weibull Ab, both of them private companies. The domestic breeding of horticultural plants was mainly in the hands of the Department of Horticulture of the ARC.

In the 1970s Finland participated in the establisment and development of the Nordic Gene Bank (NGB) and Internordic Plant Breeding (SNP) sponsored by the Nordic Council of Ministers. Finland's active cooperation with these and other international plant breeding organizations continued in the 1980s.

During this study period the main objectives of Finnish plant breeding were to produce cultivars which

- thrive well in the climate and ecological conditions of Finland;

- meet the quality demands of consumers and the food/fodder industry;

- possess good resistance to pests and diseases;

- can be adapted to mechanical cultivation;

- have high yielding potential.

These objectives call for earliness in annual plants, winter hardiness in biennials and perennials, strengthening of straw in cereals and increased amount and improved quality of protein in cereal grains and forage grasses.

The conventional breeding methods included mass and single plants selection, pedigree and bulk methods, progeny testing (polycross) and mutation breeding.

Great strices were taken in adopting basic methods of modern biotechnology, such as anther cultures, protoplast regeneration, interspecies fusion transformation and genetic engineering. The aim of these studies, conducted by several institutes, was to produce basic material for plant breeding.

The new cultivars of field crops, both domestic and foreign, were evaluated at several domestic institutes and experimental stations. On the basis of these evaluations, a special committee, established by the National Board of Agriculture in 1975, compiles an annual list of "recommended field crops varieties" to guide the farmers to select suitable cultivars. In 1978, the plant breeders agreed to delegate the responsibility for the "official variety testing"' of field crops to the Department of Plant Husbandry of the ARC. For this purpose, the country was divided into five cultivation zones and the experiments were distributed to the stations located in the appropriate cultivation zones (Fig. 2, p. 1).

A law advancement of plant breeding (1977), enacted in accordance with international organizations, gave a significant boost to Finnish plant breeding. The number of new varieties bred by Hankkija in the 1970s and

Table 1. The number of domestic varieties of field crops and lawn grasses: a) bred during 1970-1989; b) included in the list of recommended varieties for 1990 .

\begin{tabular}{|c|c|c|c|c|}
\hline \multirow[t]{2}{*}{ Plant group } & \multicolumn{2}{|c|}{ Hankkija } & \multicolumn{2}{|c|}{$\mathrm{ARC}-\mathrm{Jo}$} \\
\hline & a & b & $\mathbf{a}$ & b \\
\hline Winter cereals & 3 & 2 & 7 & $6(2)$ \\
\hline Spring cereals & 16 & 11 & 16 & $8(1)$ \\
\hline Peas & 7 & 3 & 2 & - \\
\hline \multicolumn{5}{|l|}{ Oil plants } \\
\hline Spring rape and turnip rape & 4 & 1 & 2 & - \\
\hline Potatoes & 3 & 3 & 1 & (2) \\
\hline Clovers & 1 & 1 & 0 & (3) \\
\hline Forages-hays & 3 & $2(1)$ & 5 & $5(1)$ \\
\hline Lawn grass & 3 & 3 & 2 & 1 \\
\hline \multicolumn{5}{|l|}{ Specics not in the list } \\
\hline Horse bean & 2 & - & - & - \\
\hline Smooth brome grass & - & - & 1 & - \\
\hline Winter turnip rape & 1 & - & 1 & - \\
\hline Total & 43 & $26(1)$ & 37 & $20(9)$ \\
\hline
\end{tabular}

( ) = the variety bred before 1970 
1980s was 43, and by the Department of Plant Breeding of the ARC was 37 (Table 1). The respective number of foreign varieties introduced in the 1970s and 1990s was about 100 , of which 40 were breeded in contract with Kesko-Group. The Department of Horticulture of the ARC breeded 15 varieties of small fruits and seven new varieties of apple. The number of varieties of flowers bred by the Department of Horticulture and some private nurseries was 21 . In addition, the Department of Plant breeding of $\mathrm{HU}$ developed six new varieties of rhododendron.

\section{Plant protection}

Plant protection is usually divided into three sections: pest investigations, plant pathology and weed science. Finland has special institutes for pest investigations and plant pathology at both the ARC and HU. Weed investigations, on the other hand, were a part of the programmes of the Departments of Plant Husbandry and Horticulture of the ARC until the end of 1988. When the ARC was reor-

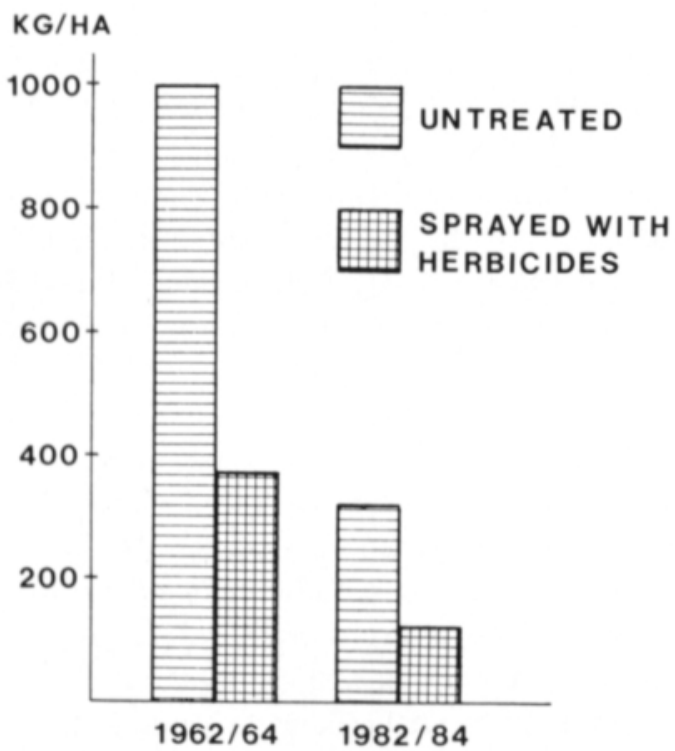

Fig. 4. The decline in the amounts of weeds in spring cereals measured as dry weight of aerial shoots, $\mathrm{kg} / \mathrm{ha}$. ganized in 1989, a special unit for weed control was established in the new Department of Plant Protection. Closer cooperation with several other institutes was established within the framework of the three sectors involved with plant protection.

Surveys of the damage, frequency and abundance of pests in cultivated plants were carried out by the Department of Pest Investigations of the ARC every other year in the 1970s and 1980s (MarkKULA 1972-1987). Similar surveys on certain plant pathogens were carried out by the Departments of Plant Pathology of the ARC and HU. The survey of weeds on winter cereals was conducted by the University of Jyväskylä in cooperation with the Department of Plant Husbandry of the ARC in the mid 1970s (M. and T. RAATIKAINEN 1978). The weed survey on spring cereals was carried out by the Plant Husbandry Department of the ARC (ERviö and SALONEN 1987). The results showed a strong decline in the abundance of weeds during the past twenty years. The dry weight of aerial weed shoots on unsprayed fields had dropped from $1000 \mathrm{~kg} /$ ha down to $320 \mathrm{~kg} / \mathrm{ha}$ and that

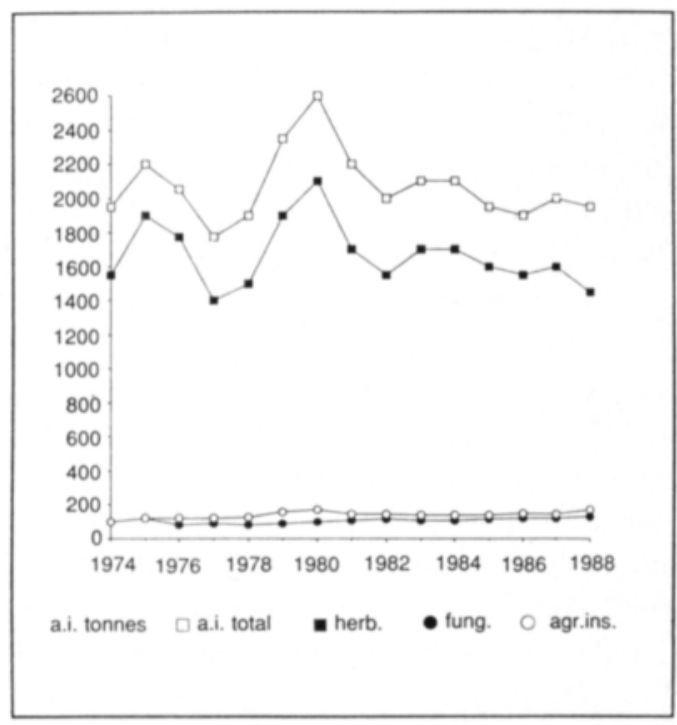

Fig. 5. Sales of pesticides calculated as active ingredients, tonnes. (Source: E.-L. Hynninen and H. Blomqvist 1989.) 
on sprayed field to $124 \mathrm{~kg} / \mathrm{ha}$ (Fig. 4). Thus the potential yield of $876 \mathrm{~kg} / \mathrm{ha}$ had been released for the utilization of cultivated plants in sprayed fields.

Methods for controlling pests, diseases and weeds shifted from chemical control to more integrated and biological control. The pesticide law was revised by new Acts $(1970,1982)$ calling for more detailed studies not only of the efficacy and safety of pesticides for cultivated plants but also of their toxicity, residues and environmental hazards. The official field experiments with pesticides were carried out mainly by four departments of the ARC, which, in this capacity, were jointly named the "'Plant Protection Institute', Some of the field experiments with pesticides were distributed to the regional experimental stations.

The Plant Protection Institute of the ARC was discontinued in 1982 . Since then responsibility for the official approval of pesticides has been delegated to the interdisciplinary Committee on Pesticides at the Ministry of Agriculture and Forestry. Several authorities, such as the institutes or boards of medicine, food, occupational safety and agricultural chemistry are represented on this committee.

Sales trends in pesticides during 1974-1988 are shown in Fig. 5. The total abundance of agricultural pesticides amounted to 1834 metric tonnes (a.i.) in 1988. The largest group, herbicides, accounted for $76 \%$ of the total. Cereal herbicides were sufficient for spraying 960000 hectares, corresponding to $79 \%$ of the total cereal acreage. The use of glyphosate for controlling quackgrass increased while the use of several other herbicides decreased. Sales of agricultural insecticides amounted to 213 tonnes, corresponding to $635000 \mathrm{hec}-$ tares, or $26 \%$ for single treatment of fields. The amount of fungicides marketed in 1988 amounted to 144 tonnes (a.i.). The major proportion of this consisted of the mercury compounds (other than alcyl mercury) used for seed treatment. Some 630000 hectares corresponding to $52 \%$ of the total cereal area was sown with treated seed. Sales of plant growth regulators amounted to 88 tonnes.

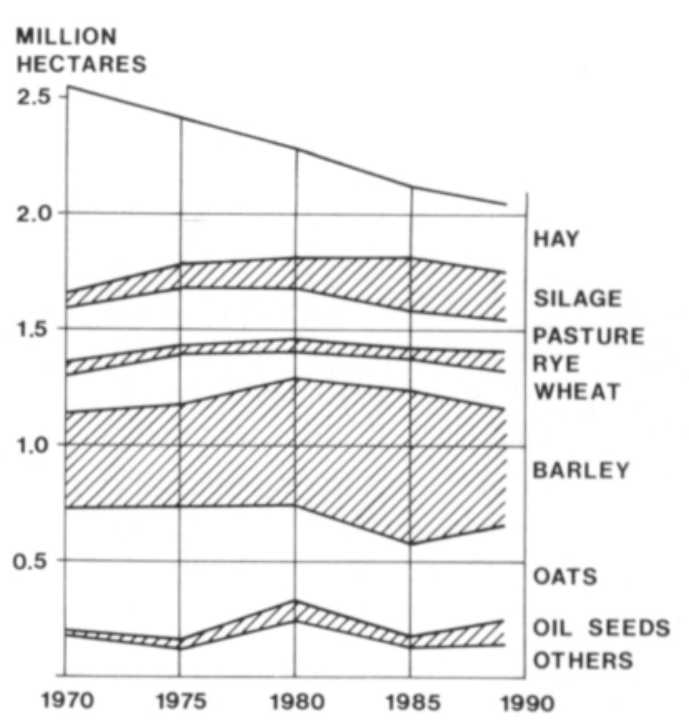

Fig. 6. The use of arable fields for major crops during the 1970 s and 1980 s.

Biological control of pest insects was initiated by Professor Martti MARKKULA (1981) at the Department of Pest Investigations of the ARC in the early 1970s. His methods replaced the major insecticides previously used in glasshouses. The techniques used by Markkula were based on the use of a) parasitic, b) carnivorous or c) pathogenic organisms for destroying the pest insects. The following commercially produced organisms were released for sale: Phytosciulus persimilis, Tetranychus urticae, Encarsia formosa and Aphidoletes aphidimyces. Successful experiments on the control of pests with the aid of pheromones, attractive trap plants and other means were carried out by other workers at the same department.

The most significant discovery in the biological control of plant pathogens was made by Dr. Risto TAHvonen (1988), who established the fungistatic properties of Streptomyces qriseoviridis. Tahvonen's method has been patented in several countries. Using fermenting techniques, Kemira began manufacturing a commercial product (Mycostop) from this Streptomyces species.

Successful studies were carried out in order to determine, test and produce healthy plant 
1000 Feed

units/ha

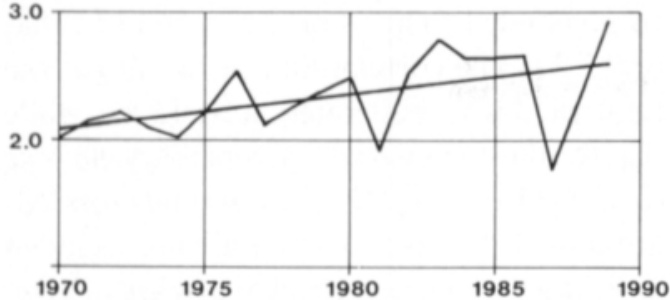

Fig. 7. The increasing trend in the yields of field crops and their variability, feed units per ha. (Source: L. Kettunen 1989.

material free of viruses. The role of antagonistic fungi, interaction between fungi and bacteria were but two of the numerous research projects that were conducted under the supervision of Professor Eeva Tapio in the Department of Plant Pathology of HU.

\section{Yields and quality of plants}

The overall trend in Finnish agriculture during the 1970s and 1980s was marked by an increase in the yield and quality of plant products - despite of the decrease in cultivated field area (Fig. 6). The average yield of field crops rose from 2032 to 2930 feed units per hectare, or $1.33 \%$ per year, thus demonstrating the significant impact of improved soil management and plant breeding (Fig. 7). A similar trend was noted in the yields of certain horticultural plants. In their, though, the improved plant protection played a more prominent role.

\section{Forage grasses and clover}

Production of field crops has traditionally been closely related to the level of animal husbandry or dairy farming in the country (cf. Poutiainen et al., in this volume). At the beginning of this study period the harvested and pastured forage grasses and clover accounted for $46 \%$ of the cultivated field area. They were grown as temporary leys in rotation with other field crops. By 1989 the proportion of forage leys was dropped to $33 \%$ of cultivated fields. Surplusproduction and high production costs had forced farmers to curtail production of forage plants.

In 1970 , as much as $92 \%$ of the harvested leys were cut and dried for hay, only $8 \%$ being prepared for silage. By 1989 the proportion of hay had fallen to $61 \%$, whereas production of silage had risen to $39 \%$. The leys for pastures and seed production are not included in the above figures.

The shift from hay to silage made for a significant improvement in the quality of forage. For example, the amount of digestible crude protein rose from $100-115 \mathrm{~g}$ to $130-165 \mathrm{~g}$ per feed unit.

Timothy had previously been cultivated in leys as mixtures with red clover. During the period of this study timothy was partly replaced by meadow fesque and cocksfoot, which have a better ability for regrowth. Red clover had previously accounted for $27 \%$ of the harvested forage mixtures. By the end of the 1960 s the proportion of clover had already fallen to $8 \%$. Apparently clover was not able to compete with grasses when higher amounts of fertilizers were used. In addition, clover hindered drying for bailing. Serious efforts were made to improve the nitrogen fixing ability of Rhizodium bacteria, growing in symbiosis with clover (SITRA 1986, UomalA 1986, Kemppainen 1987). Some success was achieved by plantbreeders in improving the resistance of clover to winter damage. Evidently the clover can still play an important role in forage production for silage and pastures.

The trend in the yield of dry hay increased from about 3600 to $4000 \mathrm{~kg} / \mathrm{ha}$ during the 1970 s and remained to this level until the end of this study period. Similarly, the yields of silage rose during the 1970 s from about 15 tonnes to 20 tonnes per hectare, likewise remaining at that level until the end of this study. The correlation coefficients for the annual variation in yield were only $7-9 \%$ in some areas of central and western Finland. Owing to frequent early summer drought the correlation coefficients rose much higher 
along the southern coast; winter damage did the same in the north. Excess nitrogen fertilization and too frequent or incorrectly timed cuttings for silage contributed to winter damage, especially in Lappland (MARJANEN et al. 1976). Some imbalance was also found in the $\mathrm{Mg} / \mathrm{K}$ ratio of the forage (TÄHTINEN 1979). Even this was caused by excessively heavy nitrogen fertilization. The imbalance was corrected by dividing the usage of nitrogen into two periods and increasing the amount of potassium in the fertilizer mixtures.

\section{Cereals}

The total area of cereal grains was about 1.2 million hectares during the 1970s and 1980 s. The acreage by species are given in Table 2. At the end of the 1980s, 74 official experiments comparing cultivars were conducted every year. Further experiments with cereals concerned the effect of fertilizers, soil management, plant protection, etc.

An increase in grain yields of cereals was significant. The estimated harvest index rose to $40-50 \%$ (KIVI 1984).

The area of winter rye declined drastically until the autumn 1988. This was due to rainy weather, which frequently prevented sowing. Special seminars were held to discuss the problems of insufficient production of winter rye. Determined efforts were made to ease the sowing problems and to introduce improved cultivars. The "trend yield" of winter rye per area unit rose from 2030 to $2320 \mathrm{~kg} / \mathrm{ha}$. This corresponded to an annual rise of $15 \mathrm{~kg} / \mathrm{ha}$, or $0.7 \%$. The correlation coefficient for the total yield was moderately low, $15 \%$, while that for the commercially acceptable yield rose to $22 \%$ (Table 2). The areas of total crop failure caused by winter damage are not included in the above figures. The worst years of crop failure were 1974, 1977, 1981 and 1988 (MuKULA and RANTANEN 1989). Of the cultivars Jussi (Hja 1975) had the best winterhardiness in snowy areas, Anna (Jo 1979) the best yield capacity and Kartano (Jo 1985) the strongest straw.

The region suitable for winter wheat is limited to the southwest of the country. The same problems were encountered in cultivation of this cereal as in that with winter rye. Year after year excessively rainy autumns reduced the area planted for winter wheat. Cultivation of winter wheat reached its lowest level in $1987 / 88$, when the harvested area was only 5400 ha. The yield of winter wheat per area unit rose from 2650 to $3080 \mathrm{~kg} / \mathrm{ha}$, when calculated according to the linear trend. This corresponded to an annual rise of $22 \mathrm{~kg} / \mathrm{ha}$, or $0.8 \%$. The correlation coefficient for the annual yield variations was $15 \%$ for the total yield and $22 \%$ for the commercially acceptable per hectare yield. These figures do not include the area of total crop failure caused by winter injuries. In 1974, the failed area exceeded $20 \%$, in $198153 \%$ and in $198445 \%$ of the planted area. An explanation for these

Table 2. The grain yields of cereal grains and their annual rise when calculated according to the linear trend. The commercial acceptability and correlation coefficients of the yields are also given.

\begin{tabular}{|c|c|c|c|c|c|}
\hline & $\begin{array}{l}\text { Winter } \\
\text { rye }\end{array}$ & $\begin{array}{l}\text { Winter } \\
\text { wheat }\end{array}$ & $\begin{array}{l}\text { Spring } \\
\text { wheat }\end{array}$ & Barley & Oats \\
\hline Trend yield in $1969, \mathrm{~kg} / \mathrm{ha}$ & 2030 & 2640 & 2655 & 2310 & 2345 \\
\hline Trend yield in $1989, \mathrm{~kg} / \mathrm{ha}$ & 2320 & 3080 & 3190 & 3070 & 3155 \\
\hline Annual rise $\quad \mathrm{kg} / \mathrm{ha}$ & 15 & 22 & 47 & 38 & 39 \\
\hline Annual rise & 0.7 & 0.8 & 1.8 & 1.5 & 1.5 \\
\hline Commercial acceptability, $\%$ & 90 & 92 & 84 & 84 & 85 \\
\hline \multicolumn{6}{|l|}{ Correlation coefficient } \\
\hline for total yield & 15 & 19 & 16 & 11 & 9 \\
\hline for commercial yield $\quad \%$ & 22 & 26 & 31 & 16 & 16 \\
\hline
\end{tabular}


exceptionally high figures for winter damage was the delayed of sowing in too wet soil. The average quality of winter wheat was reasonably good. The protein content of grains of the most common cultivars reached 11.3-12.8 \% during the $1980 \mathrm{~s}$. The highest yielding cultivar was Aura (Jo 1975), while Ilves (Hja 1984) had the hardest straw and Pitko (Jo 1985) the highest protein content.

The area of spring wheat was about 120000 ha in the early 1970 s and rose to about 175000 ha by 1975 . Owing to overproduction, the area was then reduced to a level of $100000 \mathrm{ha}$. The trend yield of spring wheat was 2655 in 1970 and $3190 \mathrm{~kg} / \mathrm{ha}$ in 1989 , corresponding to an annual rise of $47 \mathrm{~kg} / \mathrm{ha}$, or $1.8 \%$ per year. The correlation coefficient for the total yield was reasonably low, $16 \%$, but rose up to $31 \%$ in the commercially acceptable yield. This was an evidence of the exceptional vulnerability of the quality. The protein content of Finnish spring wheat showed a decreasing trend until 1985. To redress the situation a special wheat protein project was launched in 1986. The fate of the nitrogen used as fertilizer was studied in detail both in the soil and in the plants using ${ }^{15} \mathrm{~N}$ techniques. The quality of gluten protein was evaluated by using protein fractioning and test baking. The highest yielding cultivar during the period of this study was Kadett (Wb 1981), and the best resistance to lodging were showed by Luja (Jo 1981) and Polkka (Sv 1988). Heta (Hja 1988) ripened faster and had higher protein content $(15.6 \%)$ than the other varieties.

The area planted for barley grew almost constantly from 400000 ha to 680000 ha during the period of this study. The average level of the yield rose from 2310 to $3070 \mathrm{~kg}$ / ha, which corresponded to an annual rise of $38 \mathrm{~kg} / \mathrm{ha}$, or $1.5 \%$ yearly. The major weakness in barley varieties was the inadequate strength of their straw. Hence, the main effort in breeding new cultivars from barley was directed at hardening the straw. Significant improvements were seen, a development which is to be hoped will continue in the future. A special research project for malting barley was carried out in the 1980 s. The aim of this project was to produce recommendations referring specifically to the varieties cultivated for malting purpose. As to the six-row varieties HJA 673 (Hja 1973) and Arra (Jo 1982) were the earliest to ripen; their weakness was soft straw. The protein content of six-row varieties was highest in Arra. Agneta (Sv 1978), Kalle (Sv 1984 and Pohto (HJA 1986) showed significantly harder straw. In this respect the two-row varieties Ida (1979) and Kymppi (Sv 1980) were still stronger. Both were accepted not only for fodder but also for malting purposes.

The area under oats fell from about 550000 ha down to $400000 \mathrm{ha}$. The average yield rose from 2350 to $3155 \mathrm{~kg} / \mathrm{ha}$, corresponding to an annual rise of $39 \mathrm{~kg} / \mathrm{ha}$, or $1.5 \%$. The variation coefficient was moderately low, $9 \%$ for the total yield and $16 \%$ for the commercially acceptable yield. The trend in oats' breeding was towards thinning the grain husk, increasing the protein content, strengthening the straw and shortening the growing time. Two significantly improved cultivars, Puhti (Jo 1978) and Veli (Jo 1981), demonstrated the achievements of Finnish plant breeders.

\section{Other seed crops}

The only oil seed crop cultivated in Finland in the early 1970 s was winter turnip rape. Owing to its high content of harmful eruca acid the cultivation of winter turnip rape was discontinued in the mid 1970s, and it was replaced by spring turnip rape and spring rape. The plant breeders soon succeeded in freeing both of them from eruca acid. The first acceptable cultivars were obtained from Sweden and Canada. Domestic plant breeders had success to joint in the 1980 s. Problems in developing cultivation techniques for these new crops called for special research projects directed at sowing and harvesting techniques, fertilization, control of pests, weeds and diseases, etc. The quality of the oil pressed from the seeds as well as the suitability of the pressing residual for animal fodder were studied in- 
tensively. As a result, the plant breeders even succeeded in eliminating the toxic glucosinolates. The area under spring sown rapes rose consistently to almost 86000 ha in 1988 . The yield level of spring turnip rape was only $1400-1600 \mathrm{~kg} / \mathrm{ha}$, while that of spring rape was $3100-3300 \mathrm{~kg} / \mathrm{ha}$. The long growing time restricted the cultivation of spring rape to small areas along the south coast, while the turnip rape varieties thrived well in zones I and II, some of them even at the southern margin of zone III (cf. Fig. 2, p. 1). The earliest of the turnip rape varieties were Ante (Sv) and Nopsa (Jo 1986). Kova (Sv 1988) showed a significantly harder stem.

Peas have traditionally cultivated in small areas of southern and central Finland for hundreds of years. During the period of this study the area planted annually for pea was only $1500-2000$ ha and that of mixture of pea and cereals $1000-3000$ ha. The growing time of cultivars ranged from 88 to 101 days. One of the difficulties in cultivating the conventional peas was their inadequate suitability to long day conditions. They tended to continue both vegetative growing and flowering before finally lodging. Such types of pea were not suitable for mechanical harvesting. Not even supporting the pea stand with hard straw cereals gave satisfactory results. Some progress was made by plant breeders in producing fascicata types of pea with a shorter stem and blunt crown. Another interesting development was a semi-leafless type bearing strong tendrils which caused the plants to intertwine and thus prevented lodging.

\section{Potatoes and sugar beets}

The area planted for potato was reduced from 60000 to 45000 ha during the 1970 s and 1980s. The yield level, however, rose from about 16 to 20 tonnes per hectare. Factors contributing to this favourable trend were the efforts made by the Finnish Potato Growers Society, the Potato Research Institute and the Seed Potato Centre, which produced healthy planting material free of viruses. The plant- ing, cultivation and harvesting techniques of potato improved markedly as did harvest handling in storage and market, thus further contributing to the better quality of commercial potatoes. Outbreaks of dangerous diseases such as potato wart (Synchytrium), nematodes (Heterodera) and ring rot (Corynebacterium) were prevented by isolating the infected areas as specified in the international plant quarantine regulations (e.g. SEPPÄNEN and HEINÄNEN 1973, AAPro 1980). Similarly, virus diseases were submitted to special surveillance (KURPPA 1984). An interesting research project to study the glycoalkaloids (solanides) in potatoes was carried out jointly by the Department of Plant Husbandry, two experimental stations and the Central Laboratory of the ARC. High alkaloid contents were found mainly in northern areas. Detailed results of this project have not yet been published.

Sugar beet was cultivated in southern Finland over an area of 25000-32000 ha. The cultivars were breeded in contract with Swedish Hilleshög or other foreign plant breeders. The normal yield of sugar beet ranged from 25 to 30 tonnes per hectare and the sugar content from 15 to $17 \%$. The use of monogerm seed combined with selective herbicides such as chloridatzon, phenmedipham, etofumesate and metamitron made it possible to reduce the sowing density and thus to minimize the manual thinning. The herbicide spraying was usually repeated in small doses using the appropriate "tankmixtures". To optimize the use of fertilizers a special computer program was developed making it possible to reduce the use of fertilizers by $40 \%$. To increase the efficiency of the fertilizer a special placement method was developed. The fertilizer placement unit and seed units were fitted with rotary harrow. This kind of one-pass machine made it possible to sow sugar beet directly on to the plowed soil and thus effectively avoid soil compaction.

\section{Horticultural plants}

Horticulture is the most diversified and rapidly growing sector of Finnish plant pro- 
Table 3. Commercial production of horticultural plants in 1986.

\begin{tabular}{lrc}
\hline $\begin{array}{l}\text { Groups of plants } \\
\text { ha }\end{array}$ & $\begin{array}{c}\text { Area } \\
\text { Production } \\
\text { million FIM }\end{array}$ \\
\hline $\begin{array}{l}\text { On open fields } \\
\text { vegetables }\end{array}$ & 7100 & $200-250$ \\
small fruits & 7200 & 250 \\
- strawberri & 2600 & 250 \\
- black currant & 900 & \\
- others currants & 350 & 30 \\
- gooseberry & 200 & \\
- raspberry & 150 & \\
apples & 440 & 20 \\
$\quad$ nurseries & 475 & $70-80$ \\
In glass houses & & \\
$\quad$ vegetables & 235 & 540 \\
ornamentals & 120 & 600 \\
\hline
\end{tabular}

duction. Research into horticultural plants was carried out by the two horticultural institutes of the ARC and HU. The institutes of crop protection and soil science also contributed, as did some regional experimental stations and private enterprices. Even so the research into horticultural plants did not meet the expanding demand for this special sector of plant production. Future research into horticultural plants is intended to increase both basic studies and project-oriented interdisciplinary studies.

The area and market values of the major commercial horticultural plants, evaluated in 1986, are given in Table 3. Home gardens, public parks and green areas for recreation are not included in the table. The total area of commercial vegetables, small fruits and nuresery plants in open fields amounted to 12065 ha. This corresponded to FIM 500600 million per year in production value, but did not meet the domestic need. In addition, production area was too narrow. For example, the commercial production of vegetables was to a great extend limited to cabbages, cucumbers and carrots.

The estimated area of home gardens was 14000 ha in 1983 and that of public parks and green areas for sport and recreation was $2000-3000 \mathrm{~km}^{2}$. The green area was increasing by $2000-3000$ ha annually, and the amount of money spent for green areas was FIM 2.5 billion per year!

The average quality of domestic horticultural products prooved better than that of imported products. Above all, contamination by air pollutant was low. The perennial horticultural plants bred in Finland showed better winter hardiness than did imported ones.

\section{Cropping systems}

The term "cropping system"' refers to various aspects of soil management, fertilization, plant protection and plant or crop rotation. The cultivation methods of conventional cropping systems were discussed previously in this paper. The purpose has been, and still is, to achieve as effective and economic plant and crop production as possible with the aid of large quantities of fertilizers, pesticides, etc. Rotation of plants or crops was originally considered part of the conventional cropping system. Owing to the reduced number of people working in agriculture, farmers were forced to replace manual labour with agricultural machinery, which - in many cases - could be applied only to certain types of plants or crops, e.g. combined harvesters to cereals, hay balers and ensilage cutters to harvest grasses, digging machines with automatic loading systems to sugar beets and potatoes (cf. Oksanen, in this volume). Concentrating the production on only one type of plant the farmers avoided buying too many kinds of expensive machinery. Such a development inevitably led to an increasing one-sided drift and finally to monoculture. This in turn increased the vulnerability of production and caused difficulty in the control of pests, diseases and weeds, many of which are more or less specific to certain cultivated plant or crop. The chemical residues in food and feed prompted public concern about the affects on health of plant products cultivated by conventional methods.

Preliminary research into alternative cropping systems was carried out in the 1970s. A pioneer in this sector of plant production was 
Professor Eero Varis at the Department of Plant Husbandry of HU. Varis was interested in new plants, leguminous in particular, mixtures of plants differing growing types and crop rotation needs. He also explored the feasibility of avoiding the use of fertilizers and pesticides.

In the 1980s the following four large scale research projects into alternative cropping systems were carried out in Finland:

1) Biological nitrogen fixation (19811985): The project comprised several subprojects, and a number of institutes and organizations were involved in the direction of Dr. Pertti Uomala (1986).

2) Prospects for self-sufficiency in food production independent of imported energy inputs (1982-1985): The project covered crop rotation, nitrogen recovery and a subproject on composting. It was carried out by two institutes and four experimental stations of the ARC in the direction of Dr. Jouko Sippola.

3) Comparison of cropping systems (1982 -1988): This was a joint study carried out at Suitia experimental farm by sex institutes of $\mathrm{HU}$ under the direction of Professor Eeva Tapio.

4) A case study on alternative farming (1983-1986): The project was carried out on 50 farms in southern Finland under the direction of Dr. Timo Mela.

The financing of these studies was obtained mainly from the SITRA foundation, the Finnish Academy of Science and the Finnish Ministry of Agriculture and Forestry. Some cooperation between the Nordic countries was also organized by the Scandinavian Association of Agricultural Scientists (NJF) and the Nordic Contact Organ for Agricultural Research (NKJ).

In Finland, the acreage of alternative cropping systems has been minimal to date. Owing to the expansing public interest, however, the area of alternative cultivation is expected to grow in the near future.

\section{Selected litterature}

Annales Agriculturae Fenniae, Vols. 10-28 (1970-1989): Annual lists of agricultural papers published by the scientists of the institutes counted below.

\section{Agricultural Research Centre, SF-31600 Jokioinen}

Central Laboratory

Department of Agricultural Chemistry and Physics

Department of Plant Husbandry (Crop Science)

Department of Horticulture

Department of Plant Breeding

Department of Plant Pathology

Department of Pest Investigations

Department of Soil Science

Healthy Plant Centre

Martens Vegetable Research Station

University of Helsinki, SF-00710 Helsinki

Department of Agricultural Chemistry

Department of Food Chemistry and Technology

Department of Horticulture

Department of Plant Breeding

Department of Plant Husbandry

Department of Agric. and Forest Zoology

Department of Microbiology

Department of Plant Pathology

\section{Other institutes}

Assoc. Agric. Centres, Helsinki

Food Res. Lab. Techn. Res. Centre, Espoo

Grain Laboratory of State Granary, Helsinki

Inst. Biol. Jyväskylă University, Jyvăskylă

Kemira Co, Helsinki

National Board of Agriculture, Helsinki

Pesticide Bureau, Vantaa

Plant Breeding Institute of Hankkija, Hyrylä

Potato Research Institute, Lammi

Research Centre for Sugar Beet, Perniö

Res. Inst. Agric. Economics, Helsinki

Soil Analyses Service, Helsinki

State Inst. Agric. Chemistry, Helsinki

Work Efficiency Association, Helsinki

\section{Committee meetings}

Luonnonmukaisen viljelyn tutkimuksen, opetuksen ja neuvonnan kehittäminen. Komiteamietintö 1968:37. Helsinki.

Maataloustutkimuksen tavoiteohjelma. Maataloustutkimus 2000. Työryhmämietintö MMM 1987:10. Helsinki.

Puutarhapoliittinen tavoiteohjelma. Puutarha-alan järjestöt. Helsinki 1986. 